\title{
Numerical Simulating Long-Distance Emergency Rescue System for Belt Fire in Coal Mine
}

\author{
Shao Hao ${ }^{1}$, Jiang Shuguang ${ }^{1,2^{*}}$, Wu Zhengyan ${ }^{1}$, Zhang Weiqing ${ }^{2}$ and Wang Kai $^{1}$ \\ 1 School of Safety Engineering, \\ China University of Mining \& Technology, Xuzhou 221116, China \\ 2 State Key Laboratory of Coal Resources and \\ Safe Mining, Xuzhou 221008, China \\ *lcsh0915@163.com
}

\begin{abstract}
The belt fire in coal mine has the characteristics of fast burning velocity, not easily extinguishing a fire and generating a great deal of poisonous and toxic gas. Once the belt fire happens, it will result in a large number of casualties and enormous property loss, which is one of the greatest disasters that influence on the safety production in coal mine. To reduce the number of casualties and property loss caused by belt fire, the longdistance emergency rescue system for belt fire is proposed, and used to directly import the poisonous and toxic gas produced by belt lane into return airway in order to guarantee the safety of staffs working in mining area. In order to research on how the efficiency of using the system and what the system has additional impact on the ventilation system, the present study applies the approach of numerical stimulation to establish the two-dimensional model of ventilation system. After the belt fire happens, and then this paper researches on the flow laws of poisonous and toxic gas, and explores the long-distance emergency rescue system for belt fire influencing on the ventilation system and controlling the poisonous and toxic gas. The current study yields the conclusions as follows: (1) how poisonous and toxic gas produced by belt fire in different ventilation models spreads and moves in the roadway; and (2) how the long-distance emergency rescue system for belt fire influences on the ventilation system. This research has certain instructive significance and reference value for improving the level of emergency rescue about the belt fire, and reducing the number of casualties and property loss caused by belt fire.
\end{abstract}

Keywords: goaf; belt fire; emergency rescue; numerical stimulation; ventilation system

\section{Introduction}

Coal mine belt fire is one of the serious disasters that gravely threaten safety production. Conveyor belt, which has the characteristics of widely distribution, continuous distribution, etc., is different from general combustibles. Spreading speed of belt fire is relatively fast and it will produce a great deal of poisonous and toxic gas when combusting. In addition, belt conveyor, is generally installed in the intake airway. Therefore, once the belt fire happens, a great deal of poisonous and toxic gas produced by belt fire will spread to other roadways or working faces with the air in a short time. It is fast and wide spreading, which will result in mass casualties and heavy loss. In China, belt fire happened more than 40 times in the large-sized and medium-sized state-owned coal mines in 1990s, of which more than 10 times were the grave accidents, 200 
casualties and great losses. At present, coal mine generally utilizes the fire-retardant belt instead of non-fire-retardant belt. ${ }^{1}$

However, the use of the fame-retard belt only reduces the possibility of belt catching fire, and cannot inhibit fire hazard completely. A serious fire happened at the central belt conveyor in Nantun Coal Mine at 14:10, November 30th, 2000. 1 m wide x 70 m long belt, $500 \mathrm{~m}$ power and signal cable, and wood lagging of $30 \mathrm{~m}$ roadway were totally burned. The smog caused by the fire spread into Nos. 7 and 8 mining areas, and 5 persons was poisoned and sent to hospital. Besides, coal mine fire caused by the belt in downhill roadway happened in Tangnei Coal Mine, Youjiang Bureau of Mines, Baise City on January 27th, 2012. Smog involved two mining areas, namely Nos. 7 and 9. 138 persons suffered from the fire hazard, 5 of them were poisoned and hospitalized. This accident caused 2 casualties and more than 20 persons injured. $450 \mathrm{~m}$ conveyor belt was burned, and part of power supply cable and drainage facility was damaged.

At present, scholars have researched on the generation features and spread laws of combustion products of belt in the roadway. Pan Dexiang et al. carried out the experimental study on burning characteristics of two kinds of timber and fire retardant steel core belt used in the coal mine to obtain burning characteristic parameters of three kinds of materials [1]. Fan Yun et al. researched on pyrolysis dynamic characteristics for several Chinese mines conveying belt by means of thermogravimetric analysis, and concluded the release law of volatile for mine conveying belt [2]. Lowndes et al. concluded the results of an experimental and computational study conducted to characterize the initiation and spread of fire along the upper and lower surfaces of a conveyor belt mounted within a ventilated full-scale experimental fire test gallery [3]. Maria I. et al. studied that the U.S. Department of Energy Pittsburgh Research Center conducted experiments with mine conveyor belt samples in a $20-\mathrm{L}$ furnace and in a laboratory fire tunnel to measure and compare the major toxic gas concentration evolved during the combustion of the materials [4].

The spreading law of belt fire also has been received attention. De Ris firstly put forward a very comprehensive horizontal flame spread model [5]. Quintiere analyzed the utilization of flame spread theory to determine suitable parameters to characterize the fire performance of materials [6]. Later, Williams extended this work mentioned above to introduce an ignition model [7]. However, Wichman and Osman further researched on the cellulosic materials [8]. Besides, Apte et al. investigated fire propagation across ventilated solid polymeric surfaces in order to view to applying the findings to conveyor belts in coal mines [9]. Karlsson et al. further developed the ignition flame model [10]. Quintiere carried out the experimental studies of developing an expression for the flame height, and successfully made use of correlation methods to estimate the flame height from heat flux measurements [11]. Karlsson combined combine the experimental results of Quintiere with the mathematical model of Wichman and Osman [8], and proposed a simple mathematical model [10]. Grant et al. further contributed to this model by including the effect of "burn out"[12]. Lowndes et al. proposed a novel discrete particle-based model to represent the physical presence, combustion and flame spread along the conveyor belt surface, using a gallery model about $2 \mathrm{~m} * 2 \mathrm{~m} * 31 \mathrm{~m}[3]$. Liming Yuan presents numerical and experimental results characterizing a conveyor belt fire in a large-scale tunnel using NIOSH Fire suppression facility, and developed A CFD model to simulate the flame spread over the conveyor belt in a mine entry [13]. In addition, Stefopoulos et al. used VnetPC 2003 software to examine the design of an emergency ventilation system, which will provide the necessary control of smoke and heated gases within an underground warehouse facility, in case a fire occurs, and they also took three scenarios with different modification of the area into consideration and used regulators installation or stopping installation [14].

Jiang Shuguang is the corresponding author. 
With respect to belt fire, automatic-spray device is usually installed in the belt. Once the smog is detected, the automatic-sprat device will start to work and extinguish the belt fire in the seminal state. However, very little attention has been given to taking measures to carry out rescue after the fire happens.

In order to reduce the harm of belt fire to workers in the mining area, this study has developed the belt fire long-distance emergency rescue system (Hereinafter cited as fire emergency rescue system). Automatically adjusting the air flow from long distance can effectively control the scope of direct smoke-assaulted area, and avoid the casualties. As is shown in Figure 1, cross heading is dug between the belt roadway and return airway at the place of entering mining area. Normal close rescue doors, namely FM1 and FM2, were structured in the cross heading. Additionally, normal open rescue doors, FM3 and FM4 were respectively established in belt roadway. When the fire happens, FM1 and FM2 will open automatically, and FM3 and FM4 will close by themselves. That prevented the smog into mining area, and smog directly entered into the return airway through the cross heading, which guaranteed the workers in the mining area to be safe.

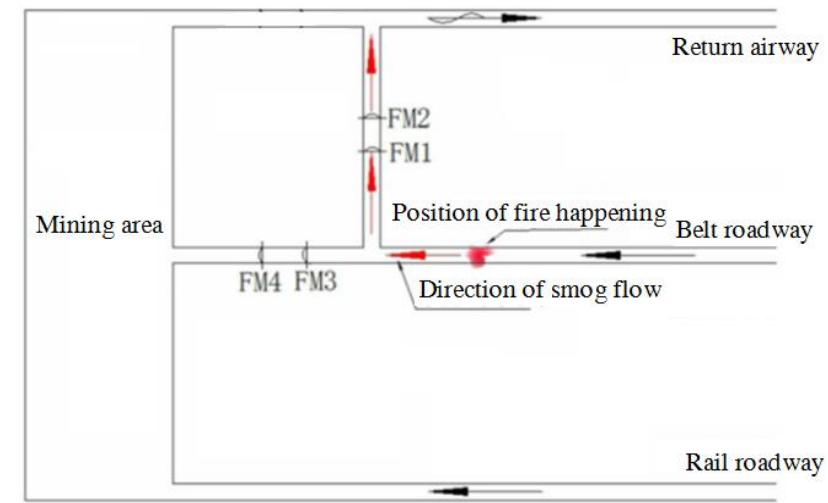

Figure 1. Schematic Diagram of Long-Distance Monitoring System for Emergency Rescue in Coal Mine

Owing to be difficult to carry out experiment underground, In order to research the effect of using fire emergency rescue system and the influence on ventilation system. this study used the CFD, launched a major effort in the numerical simulation analysis of fire emergency rescue system for N3 mining area of Changcun Coal Mine. In this paper, it investigated the spread flow law of poisonous and toxic gas, and the effect of fire emergency rescue system and its influence on ventilation system.

\section{Physical Model of Ventilation System}

\subsection{Establishment of Two-Dimension Physical Model of Ventilation System}

Changcun Coal Mine of Lu'an Group is located at the Tunliu County, Shanxi Province. The trend of Coalfield is $17 \mathrm{~km}$ and its run east-west is $7.4 \mathrm{~km}$. Minable reserves are 94399.2 tons, and No3 is the mainly mining coal seam. Average thickness is $6.02 \mathrm{~m}$, and annual production capacity reaches 700 tons. The coal mine is divided into south and north wings. The north wing contains three mining areas, namely N1, N2 and N3, while the south wing consists of six mining areas, that is, S1, S2, S3, S4, S5 and S6. At present, it mainly mines N3 and N5. There are three intake airways (i.e. North-wing belt roadway, North-wing rail roadway, and North-wing auxiliary intake airway) and two return airways (i.e. North-wing return airway and North-wing No.2 return airway) that are connected with north No.3 mine area. Currently, No.3 mine area in north is comprised of working faces (i.e. N3-3, N3-7, N3-8,etc.), intake airways of mine area (i.e. $\mathrm{N} 3$ belt uphill,N3 rail uphill) and return airways of the mining area (i.e.N3-No.1 return air downhill,N3-No.2 
return air downhill ). According to the double-line graphics of ventilation system, the two-dimensional physical model of ventilation system for north No.3 mining area was established in the use of auto CAD, and GAMBIT was used to divide the physical model into grids which ranged from $0.268 \mathrm{~m} 2$ to $2.363 \mathrm{~m} 2$, totally 108175 grids, as is shown in Figure 2.

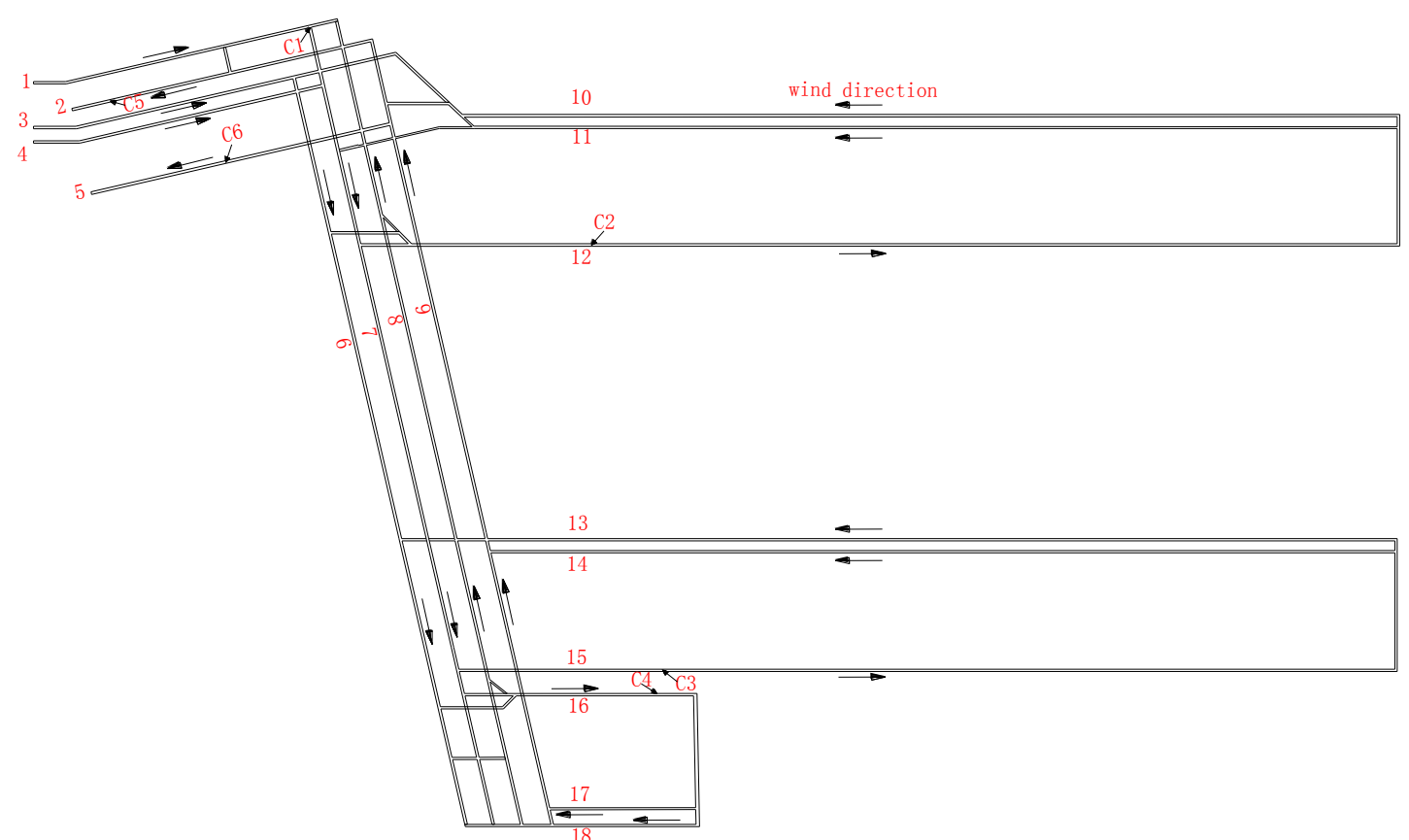

1, North-wing belt roadway; 2, North-wing return airway; 3, North-wing rail roadway; 4, North-wing auxiliary intake airway; 5, North-wing No.2 return airway; 6, N3 rail uphill; 7, N3 belt uphill; 8, N3-No.1 return air downhill; 9, N3-No.2 return air downhill; 10, N3-3rail downwind slot; 11, N3-3gas drainage roadway; 12, N3-3belt downwind slot; 13, N3-7rail downwind slot; 14, N3-7gas drainage roadway; 15, N3-7belt downwind slot; 16, N3-8 belt downwind slot;17, N3-8gas drainage roadway; 18, N3-8rail downwind slot

\section{Figure 2. Physical Model of Ventilation System for N3 Mining Area}

\subsection{Design of Combustion Zone}

Belt fire may happen in the North-wing belt roadway and N3 belt uphill of the large roadway. However, North-wing belt roadway is much longer compared to N3 belt uphill. Besides, it is frequently used. Consequently, it is most likely that fire happens. The present study simulated the smog flow law of North-wing belt roadway at the beginning of combusting, and combustion zone is shown in Figure 3. The normal close rescue door was installed in the cross heading that connected North-wing belt roadway and Northwing return airway. Between North-wing belt roadway and N3 belt uphill, the normal open rescue door was also installed. The normal open and close rescue doors were both installed at the junction of the two roadways for ease of establishing model, illustrated in Figure 3. In a normal ventilation situation, the normal close rescue door is close, while the normal open one is open. Whereas, after fire emergency rescue system begins to work, that is, it is in a rescue ventilation situation, it is the other way round. 


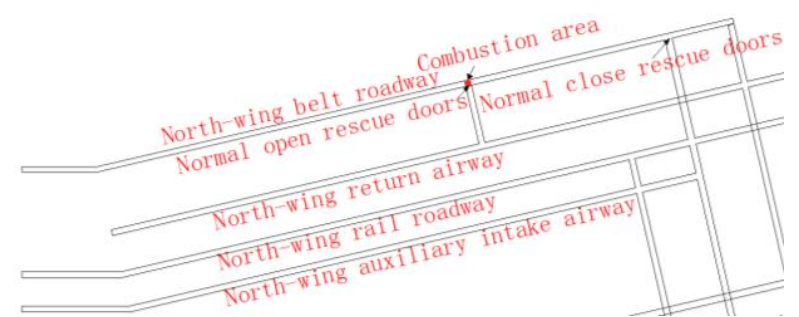

Figure 3. Location of Combustion Zone and Setting of Rescue Door

\section{Mathematical Model and Boundary Condition}

\subsection{Belt Combustion}

(1) Products. The products caused by belt fire were complicated and had no quantitative gas components. To this end, the chemical equation for coal and oxygen reaction is used to show the products of belt combustion and the proportion of components [15]. The chemical equation is as follows:

$\mathrm{Coal}+\mathrm{O}_{2} \rightarrow \mathrm{CO}_{2}+0.1 \mathrm{CO}+$ heat

In the equation above, it is clear that consuming $1 \mathrm{~mol}$ oxygen can generate $1 \mathrm{~mol} \mathrm{CO}_{2}$ and $0.1 \mathrm{~mol} \mathrm{CO}$.

(2) Generation rate. With the continuation of belt combustion, the heat coming from belt combustion gradually accumulated, and the temperature of belt surface and environment increased gradually. In addition, the combustion rate of belt showed a gradual increase. In this paper, the environmental temperature stays at room temperature without consideration of generating heat from belt fire. The combustion rate of belt is also a steady state value: reactant $\mathrm{O}_{2}$ is $0.05 \mathrm{Kg} / \mathrm{m}^{3} \cdot \mathrm{s}$, and resultant $\mathrm{CO}_{2}$ and $\mathrm{CO}$ is respective $0.069 \mathrm{Kg} / \mathrm{m}^{3} \cdot \mathrm{s}$ and $0.0044 \mathrm{Kg} / \mathrm{m}^{3} \cdot \mathrm{s}$.

\subsection{Basic Mathematical Model}

This research mainly simulated spreading laws of $\mathrm{CO}_{2}, \mathrm{CO}, \mathrm{O}_{2}, \mathrm{~N}_{2}$, etc. that generated by belt combustion in the roadway. The basic equations are shown in Table 1 .

Table 1. Basic Mathematical Model of Poisonous and Toxic Gases Spreading in Roadway

\begin{tabular}{|l|c|}
\hline $\begin{array}{l}\text { Mass-conservation } \\
\text { equation }\end{array}$ & $\frac{\partial \rho_{f}}{\partial t}+\frac{\partial\left(\rho_{f} u_{i}\right)}{\partial x_{i}}=s_{m}$ \\
\hline $\begin{array}{l}\text { Momentum- } \\
\text { conservation equation }\end{array}$ & $\frac{\partial}{\partial t}\left(\rho_{f} u_{i}\right)+\frac{\partial\left(\rho_{f} u_{i} u_{j}\right)}{\partial x_{j}}=-\frac{\partial p}{\partial x_{i}}+\mu \frac{\partial^{2}}{\partial x_{i} \cdot \partial x_{j}} u_{i}+\frac{\mu}{3} \frac{\partial}{\partial x_{i}}\left(\frac{\partial u_{j}}{\partial x_{j}}\right)+\rho_{f} g+s_{i}$ \\
\hline $\begin{array}{l}\text { Component transport } \\
\text { equation }\end{array}$ & $\frac{\partial}{\partial t}\left(\rho_{f} Y_{n}\right)+\frac{\partial}{\partial x_{i}}\left(\rho_{f} u_{i} Y_{n}\right)=\frac{\partial}{\partial x_{i}} \vec{J}_{n}+R_{n}+S_{n}$ \\
\hline $\begin{array}{l}\text { Energy conservation } \\
\text { equation }\end{array}$ & $\frac{\partial}{\partial t}\left(\varepsilon \rho_{f} E_{f}+(1-\varepsilon) \rho_{s} E_{s}\right)+\frac{\partial}{\partial x_{i}}\left(u_{i}\left(\rho_{f} E_{f}+p\right)\right)=\frac{\partial}{\partial x_{i}}\left(k_{e f f} \frac{\partial T}{\partial x_{i}}\right)-\frac{\partial}{\partial x_{i}} \sum_{n} h_{n} \vec{J}_{n}+\Phi+S_{f}^{h}$ \\
\hline
\end{tabular}

\subsection{Boundary Condition}

This study used FLUENT to carry out mathematical simulation. Before simulation, it is necessary to set the boundary condition. Owing to the two-dimensional model with little regard to height, the height of roadway is higher than that of ordinary roadway in the special roadways (such as monorail crane roadway), and simulation flow speed is higher when simulation flow is equivalent to real flow. The focus of this paper is mainly on the 
concentration distributions of poisonous and toxic gases in the roadways. Because of this, it should firstly guarantee that simulation flow is the same as the real flow in the process of mathematical simulation. The mainly air amounts of intake and return airways in N3 mining area is illustrated in Table 2. North-wing belt roadway, North-wing rail roadway and North-wing auxiliary intake airway were set as the entrances of pressure, while North-wing return airway and North-wing No.2 return airways were set as the exits of pressure. Adjusting pressure values of each entrance and exit served to guarantee that the air amount in simulation was the same as the real air amount. From the results of mathematical simulation, the air amounts of intake and return airways are shown in Table 3 (the air density is $1.17 \mathrm{Kg} / \mathrm{m}^{3}$ in the process of numerical simulation). As noted in Table 3 , the air amounts of intake and return airways can basically reflect the real air amounts, and the error ranges from $-2.2 \%$ to $0.5 \%$.

Table 2. Main Air Amounts of Intake and Return Roadways in N3 Mining Area

\begin{tabular}{cccccc}
\hline $\begin{array}{c}\text { Roadway } \\
\text { name }\end{array}$ & $\begin{array}{c}\text { North-wing } \\
\text { belt roadway }\end{array}$ & $\begin{array}{c}\text { North-wing } \\
\text { rail roadway }\end{array}$ & $\begin{array}{c}\text { North-wing } \\
\text { auxiliary } \\
\text { intake airway }\end{array}$ & $\begin{array}{c}\text { North-wing } \\
\text { return airway }\end{array}$ & $\begin{array}{c}\text { North-wing } \\
\text { No.2 return } \\
\text { airway }\end{array}$ \\
\hline $\begin{array}{c}\text { Air } \\
\text { amount } \\
\mathrm{m}^{3} / \mathrm{min}\end{array}$ & 700 & 4260 & 3140 & 3170 & 4930 \\
\hline
\end{tabular}

Table 3. Main Air Amounts of Intake and Return Roadways in N3 Mining Area in the Process of Numerical Stimulation

\begin{tabular}{cccccc}
\hline $\begin{array}{c}\text { Roadway } \\
\text { name }\end{array}$ & $\begin{array}{c}\text { North-wing } \\
\text { belt roadway }\end{array}$ & $\begin{array}{c}\text { North-wing } \\
\text { rail roadway }\end{array}$ & $\begin{array}{c}\text { North-wing } \\
\text { auxiliary } \\
\text { intake airway }\end{array}$ & $\begin{array}{c}\text { North-wing } \\
\text { return airway }\end{array}$ & $\begin{array}{c}\text { North-wing } \\
\text { No.2 return } \\
\text { airway }\end{array}$ \\
\hline $\begin{array}{c}\text { Air amount } \\
\text { Kg/s }\end{array}$ & 13.36 & 83.48 & 61.50 & 62.03 & 96.31 \\
$\begin{array}{c}\text { Air amount } \\
\mathrm{m}^{3} / \text { min } \\
\text { error }\end{array}$ & 685.13 & 4281.03 & 3153.85 & 3181.02 & 4938.97 \\
\hline
\end{tabular}

Poisonous and toxic gases generated by belt fire were added into model through the method of setting source, and the opening and closing of rescue doors were realized by controlling its types of boundary condition.

\section{Results and Discussion}

\subsection{Simulation Results}

The process of simulation was divided into three stages. First of all, the simulation was processed at the normal condition of ventilation when there was no belt combustion. As for the second stage, when belt was combusting, the simulation was carried out at the normal condition of ventilation after the basically convergence of iterative process, the results illustrated in Table 4 . With respect to the third stage, the distributions of poisonous and toxic gases were simulated after the fire emergency rescue system was opened (i.e. normal close door was opened and normal open door was closed), as shown in Table 5. Because the physical model is relatively large and the length of this paper is limited, Table 4 and Table 5 only reflect distribution of gases in part of mining area. Six measure points were set in order to reflect the distribution of gas concentrations of the whole mining area, shown in Figure 2 and Table 4. Table 5 presents the distribution of main gas components of each measure point at different ventilation modes. 
Table 4. Measure Points and their Corresponding Names

\begin{tabular}{|c|c|c|c|c|c|c|}
\hline $\begin{array}{l}\text { Measure } \\
\text { points }\end{array}$ & $\mathrm{C} 1$ & $\mathrm{C} 2$ & C3 & $\mathrm{C} 4$ & C5 & C6 \\
\hline $\begin{array}{l}\text { Corresponding } \\
\text { roadways }\end{array}$ & $\begin{array}{l}\text { Air door } \\
\text { of North- } \\
\text { wing belt } \\
\text { roadway }\end{array}$ & $\begin{array}{c}\text { N3-3belt } \\
\text { downwind } \\
\text { slot }\end{array}$ & $\begin{array}{l}\text { N3-7belt } \\
\text { downwind } \\
\text { slot }\end{array}$ & $\begin{array}{c}\text { N3-8 belt } \\
\text { downwind } \\
\text { slot }\end{array}$ & $\begin{array}{l}\text { North- } \\
\text { wing } \\
\text { return } \\
\text { airway }\end{array}$ & $\begin{array}{l}\text { North- } \\
\text { wing 2\# } \\
\text { return } \\
\text { airway }\end{array}$ \\
\hline
\end{tabular}

Table 5. Concentrations of Gases in each Measure Point in Different Ventilation Modes after the Belt Fire Happens

\begin{tabular}{cccccccc}
\hline $\begin{array}{c}\text { Ventilation } \\
\text { mode }\end{array}$ & & $\mathrm{C} 1$ & $\mathrm{C} 2$ & $\mathrm{C} 3$ & $\mathrm{C} 4$ & $\mathrm{C} 5$ & $\mathrm{C} 6$ \\
\hline Normal & $\mathrm{O}_{2} \%$ & 13.13 & 19.99 & 19.25 & 20.65 & 19.91 & 20.16 \\
ventilation & $\mathrm{CO}_{2} \%$ & 8.41 & 0.80 & 1.65 & 0.03 & 0.89 & 0.61 \\
mode & $\mathrm{CO} \mathrm{ppm}$ & 8393 & 703 & 1658 & 0 & 904 & 603 \\
Rescue & $\mathrm{O}_{2} \%$ & 17.96 & 20.58 & 20.58 & 20.58 & 19.71 & 20.58 \\
ventilation & $\mathrm{CO}_{2} \%$ & 2.92 & 0.03 & 0.03 & 0.03 & 0.99 & 0.03 \\
mode & $\mathrm{CO} \mathrm{ppm}$ & 2892 & 0 & 0 & 0 & 964 & 0 \\
\hline
\end{tabular}

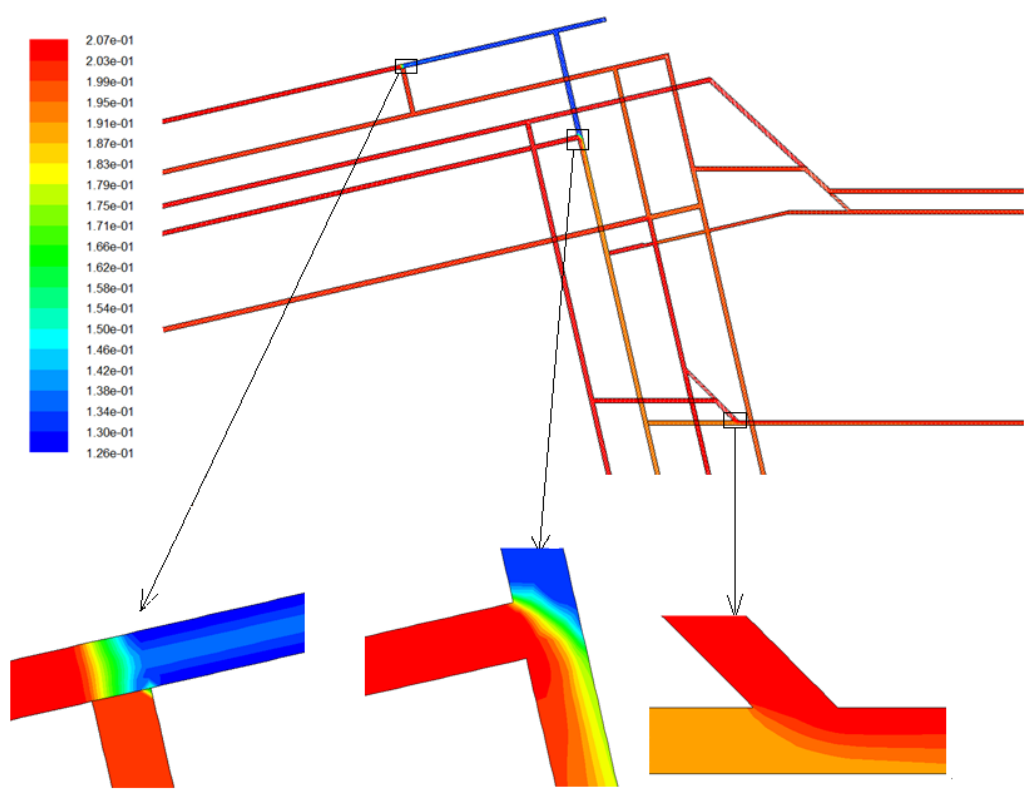

(a) Distribution of $\mathrm{O}_{2}$ 


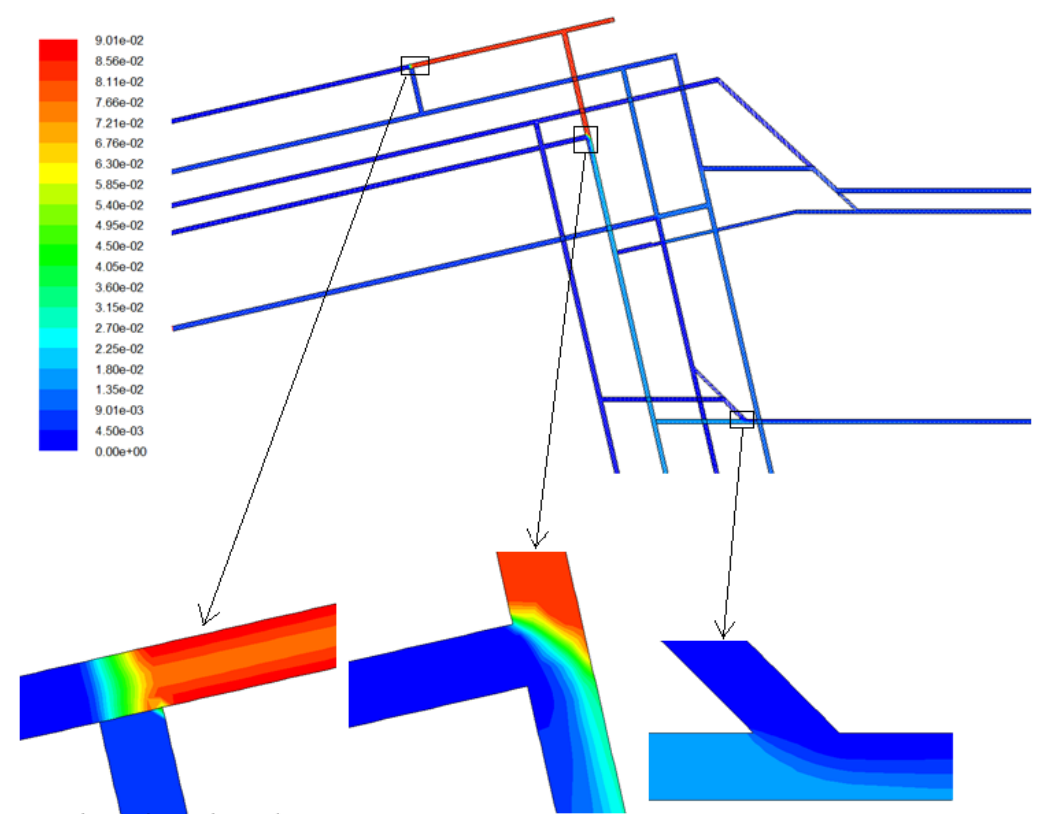

(b) Distribution of $\mathrm{CO}_{2}$

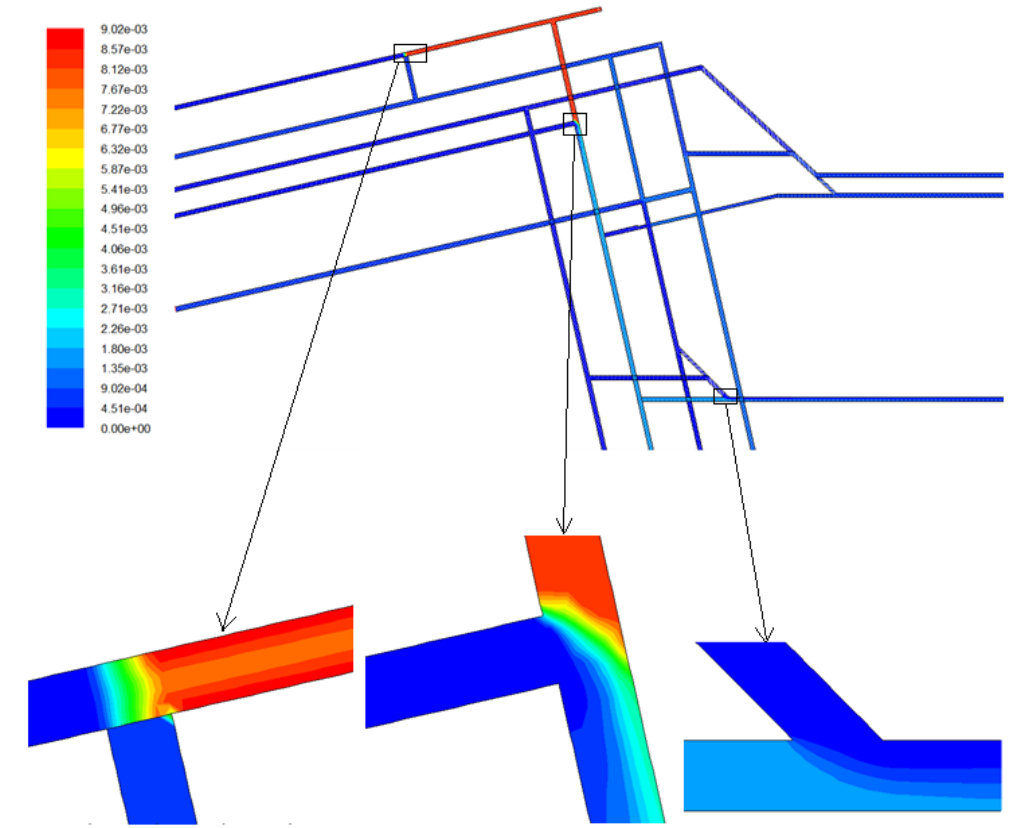

(c) Distribution of $\mathrm{CO}$

Figure 4. Distribution of Poisonous and Toxic Gases in the Roadway in the Condition of Normal Ventilation after the Belt Fire Happens 


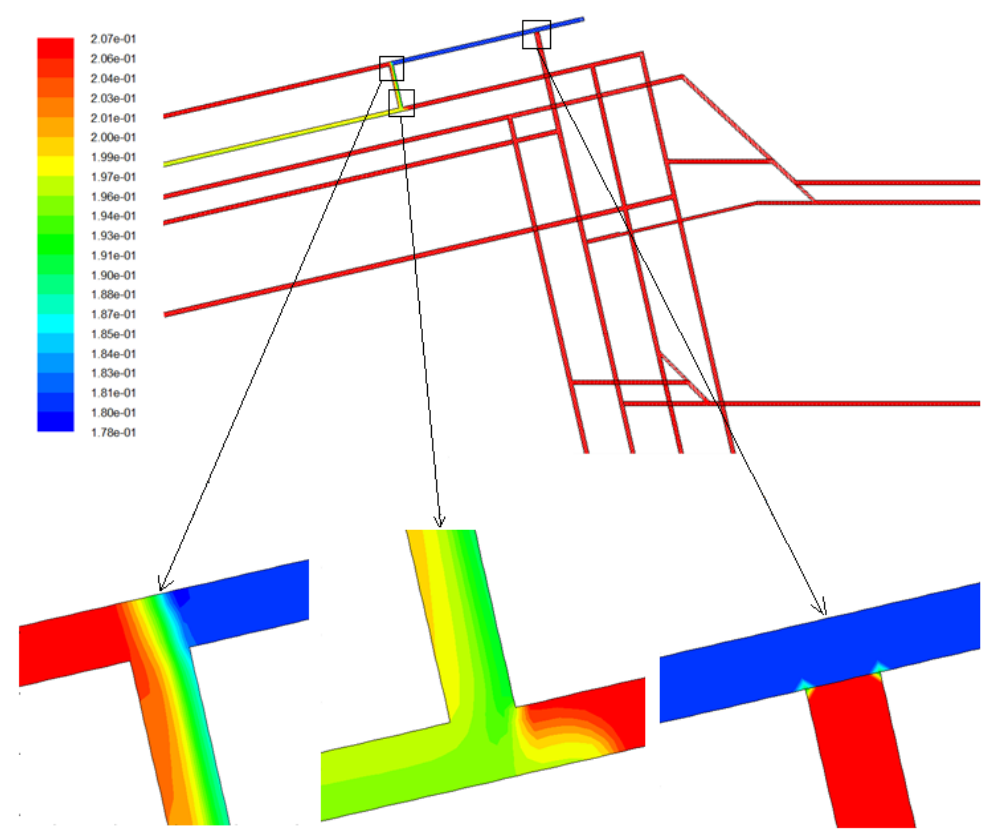

(a) Distribution of $\mathrm{O}_{2}$

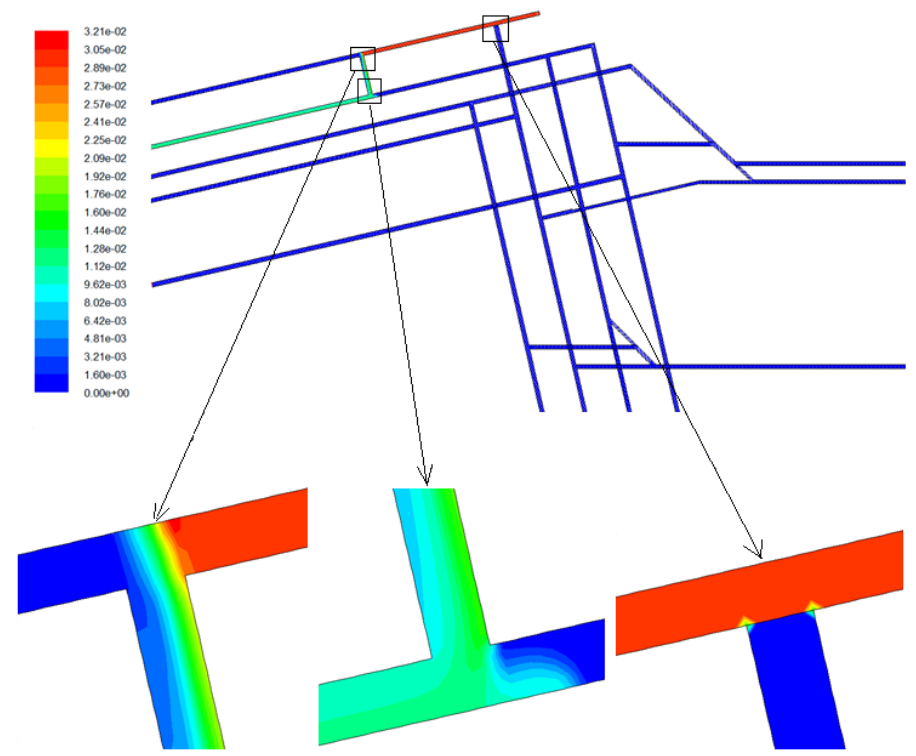

(b) Distribution of $\mathrm{CO}_{2}$ 


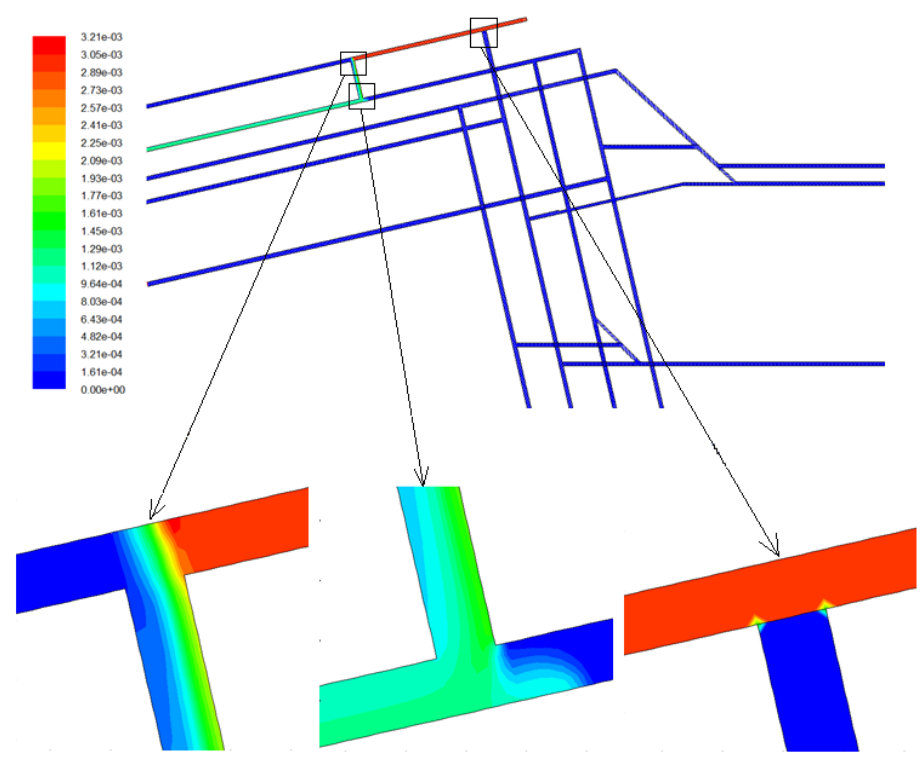

(c) Distribution of $\mathrm{CO}$

Figure 5. Distribution of Poisonous and Pernicious Gases in the Roadway in the Condition of Starting the Long-Distance Emergency Rescue System after the Belt Fire Happens

\subsection{Discussion}

(1) In the normal condition of ventilation, oxygen concentration decreased rapidly at the leeward side of belt fire site, as illustrated in Figure 4. The lowest point of oxygen concentration was only $12.6 \%$. However, the concentrations of carbon dioxide and monoxide rose rapidly, and their highest concentrations reached $9.02 \%$ and $9020 \mathrm{ppm}$, respectively. The poisonous and toxic gases generated by belt combustion spread to North-wing belt roadway, N3 belt uphill as well as N3-3 and N3-7 working faces with the air flow. With the supplement of fresh air of Northwing rail roadway and North-wing auxiliary intake airway, the concentrations of poisonous and toxic gases gradually declined, while oxygen concentrations gradually went up. The concentrations of oxygen and carbon dioxide in N3-3 working face were all in the reasonable scope. However, the concentration of carbon monoxide was far beyond the concentration that coal mine safety regulation had set and reached $600 \mathrm{ppm}$ above. From Figure 5, it is clear that the poisonous and toxic gases were controlled in North-wing belt roadway and North-wing return airway after the fire emergency rescue system was opened. Thus, other roadways were safe.

(2) After fire happened in the North-wing belt roadway, the concentrations of poisonous and toxic gases were different at the leeward side of each working face. As is shown in Table 5, the concentrations of carbon monoxide were $703 \mathrm{ppm}, 1658$ ppm and 0 ppm for N3-3, N3-7 and N3-8 of belt downwind slot, respectively. As is seen from Table 3, intake air amounts of North-wing rail roadway and North-wing auxiliary intake airway are higher than that of North-wing belt roadway, which results in that intake air amount and pressure of $\mathrm{N} 3$ rail uphill are higher than that of N3 belt uphill. Air flow entered into N3 belt uphill or belt downwind slot of working face through N3 rail uphill, and smog flow couldn't intrude into N3 rail uphill. Thus, the air in N3 rail uphill could not be polluted from the beginning to the end. As shown in Figure 4, poisonous and toxic gases in N3-3 working face were effectively diluted and their concentrations were lower than that in $\mathrm{N} 3$ belt uphill when the air flow in $\mathrm{N} 3$ rail uphill and N3 belt uphill entered into N3-3 working face together. In particular, when the entire air amount in the working faces, such as 
N3-7 working face, was provided by N3 belt uphill, the concentrations of poisonous and toxic gases in working face were relatively higher, and the possibility that workers in working face suffered from risk increased. When the entire air amount in working face, such as N3-8 working face, was provided by N3 rail uphill, the concentrations of poisonous and toxic gases in working face were relatively lower, and even reached zero. At this situation, the workers in working face were less affected by risk, and even no risk, as illustrated in Figure 6. This situation will certainly happen in special cases: when the air pressure of N3 rail uphill is higher than that of $\mathrm{N} 3$ belt uphill, the poisonous and toxic gases in belt uphill are not allowed to enter into N3 rail uphill; when the pressures at the entrance of N3-8 and N3-7 belt downwind flow are equivalent to each other and the pressure in N3 rail uphill is higher than that at the entrance of N3-8 belt downwind flow, the N3-8 belt downwind flow is all provided by N3 rail uphill; therefore, N3-8 belt downwind slot is not affected by the poisonous and toxic gases, as shown in Figure 7.

From the analysis above, each working face at the leeward side of fire had some differences in air amounts, ventilation modes and so forth, and the distributions of poisonous and toxic gases were also different. Through the reasonable adjustment, the region invaded by smog was reduced to the greatest extent. In order to prevent disaster and control risk, we should pay attention to the reasonable air flow in each roadway for daily ventilation management. Meanwhile, concentration distribution of poisonous and toxic gases at distinct points of different working faces should be predicted after the fire happens, which will conduce to drawing reasonable scheme of controlling air and scientific path of avoiding disaster.

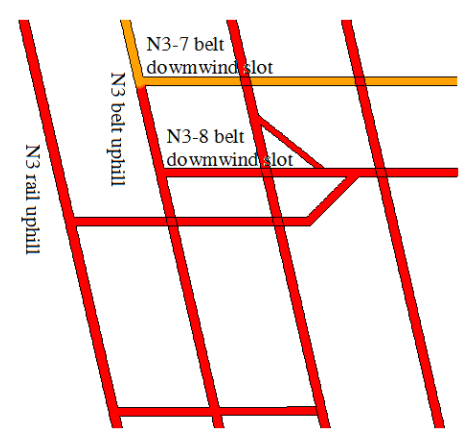

(a) Oxygen concentration field field

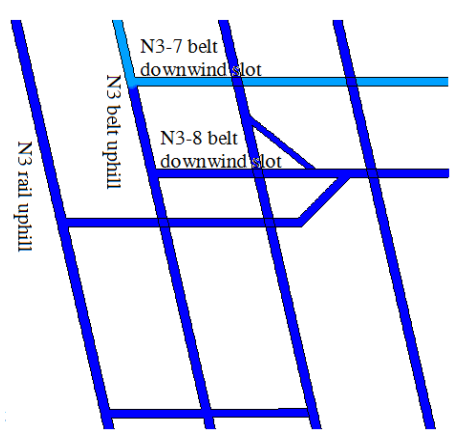

(b) $\mathrm{CO}_{2}$ concentration field

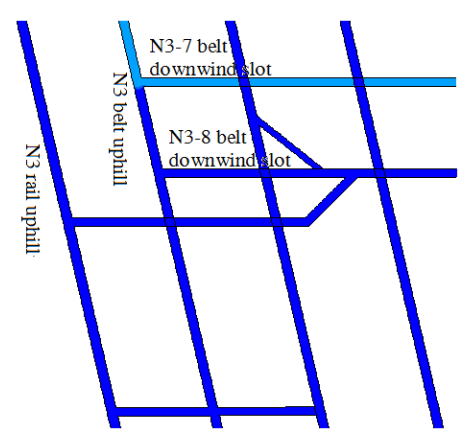

(c) $\mathrm{CO}$ concentration

Figure 6. Distributions of the Gas Concentrations in the Belt Crossheading for N3-7 and N3-8 Working Faces

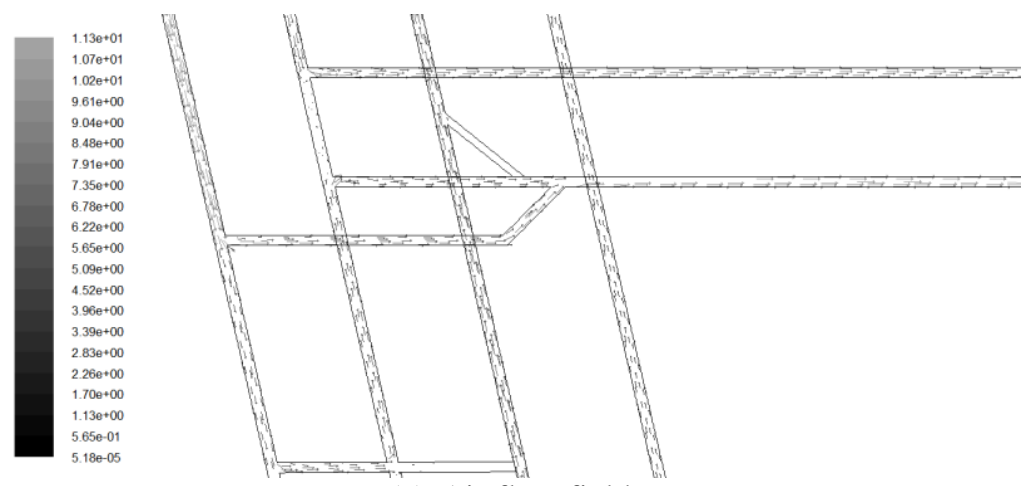

(a) Air flow field 

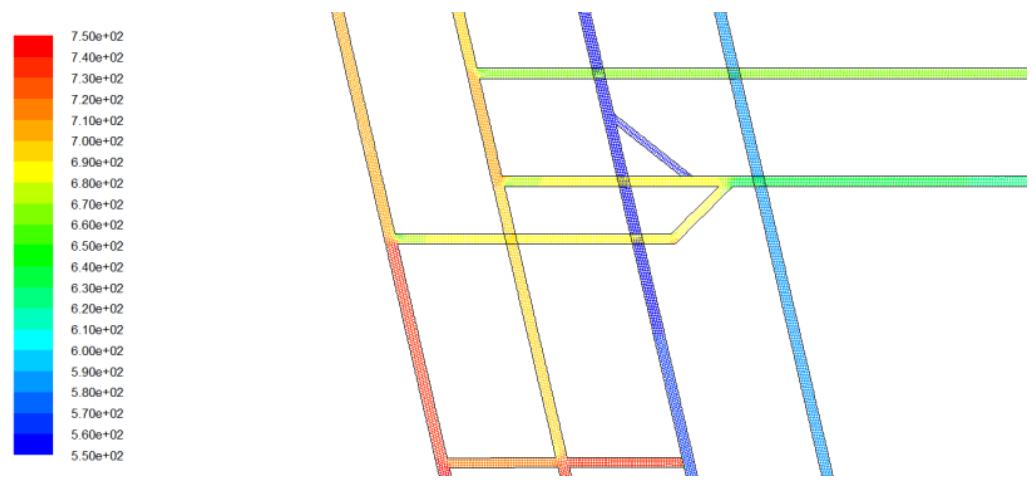

(b) Pressure field

\section{Figure 7. Distributions of Airflow and Pressure Fields in the Belt Crossheading for N3-7 and N3-8 Working Faces}

(3) After the fire emergency rescue system was opened, North-wing belt roadway was directly connected with North-wing return airway, which resulted in that air flow shorted out, wind resistance reduced and air amount increased, as noted in Table 6. Given that the amount of poisonous and toxic gases remained stable, their concentrations went down. That conduced to the quickly withdrawal of workers at this place, as seen in Figure 5. However, the increase of air amount would accelerate the speed of combustion, and finally gases concentrations would gradually increase, which should be paid special attention.

Table 6. Air Amount of each Roadway after the Emergency Rescue System Starts

\begin{tabular}{cccccc}
\hline $\begin{array}{c}\text { Roadway } \\
\text { name }\end{array}$ & $\begin{array}{c}\text { North-wing } \\
\text { belt roadway }\end{array}$ & $\begin{array}{c}\text { North-wing } \\
\text { rail roadway }\end{array}$ & $\begin{array}{c}\text { North-wing } \\
\text { auxiliary } \\
\text { intake airway }\end{array}$ & $\begin{array}{c}\text { North-wing } \\
\text { return airway }\end{array}$ & $\begin{array}{c}\text { North-wing } \\
\text { 2\# return } \\
\text { airway }\end{array}$ \\
\hline $\begin{array}{c}\text { Air amount } \\
\text { Kg/s } \\
\begin{array}{c}\text { Air amount } \\
\mathrm{m}^{3} / \text { min }\end{array}\end{array}$ & 90.16 & 80.87 & 51.39 & 97.21 & 125.20 \\
\hline
\end{tabular}

\section{Conclusions}

(1) After the fire happened in belt roadway, the concentrations of poisonous and toxic gases were different in each working face and roadway at the leeward side. The spreading scope of poisonous and toxic gases was related to air amount, air pressure and roadway layout, etc. A good ventilation system should try to reduce the concentrations and intrusion range of poisonous and toxic gases through above adjustment. Therefore, making the pre-arranged scheme of fire emergency rescue should take this feature into consideration.

(2) After the fire happened in the belt roadway, the fire emergency rescue system could effectively control the intrusion range of poisonous and toxic gases, and the intrusion range of smog was controlled in the belt roadway and adjacent return airway. Other roadways were at the normal state of ventilation and did not be affected.

(3) After the fire emergency rescue system was opened, the ventilation modes in disaster region was changed, and air amounts of each roadway related to the disaster region changed too. In particular, short-cut of air flow occurred in belt roadway and return airway, and the air amount abruptly increased. At this situation, the concentrations of poisonous and toxic gases slightly decreased for a short time, which helped the workers withdraw from the accident region quickly. However, it was not conducive to 
extinguishing fire in belt roadway. Consequently, after opening rescue system, attention should be paid to the adjusting air amount in belt roadway, which provided advantageous conditions for extinguishing fire.

\section{Acknowledgements}

The work is supported by the National Natural Science Foundation of China (Grant No. 51504251), the National Natural Science Foundation of Jiangsu of China (No.BK20140187), the Priority Academic Program Development of Jiangsu Higher Education Institutions, and the National Natural Science Foundation of Jiangsu of China (No. BK20130203), the Central Universities Special Funds for Fundamental Research Funds of the China University of Mining and Technology (No. 2014ZDPY04), the Innovation Team of CUMT (2014QN001), and the Natural Science Foundation of Jiangsu Province (No.BK2012571).

\section{References}

[1] P. Dexiang, Y. Shousheng, S. Zhongjun, "Experimental Study on Burning Characteristics of Fire retardant Steel Core Belt and Mine Timber" China Safety Science Journal, vol.12, no.12, (2005), pp.5759.

[2] F. Yun, H. Liantao, D. Jian. "Study on Phrolytic Dynamic Characteristic for Mine Conveyer Belts", Journal of China University of Mining and Technology, vol.27, no.3, (1998), pp.291-293.

[3] I.S. Lowndes, S.A. Silvester, D. Giddings, et al, "The computational modelling of flame spread along a conveyor belt". Fire Safety J ,vol.42, (2007), pp.51-67.

[4] M. De Rosa, "I. A 20-liter Furnace Test Method to Determine the Combustion Gas Toxicity on Conveyer Belts". US Department of Energy, Pittsburgh Research Center (1996).

[5] JN De Ris. "Spread of a laminar diffusion flame. Twelveth symposium (international) on combustion"(1969) December; Elsevier, vol.12, no.1, pp. 241-252.

[6] J. G Quintiere and M. Harkleroad, "New concepts for measuring flame spread properties", Fire Safety Science and Engineering, ASTM STP, vol.882, (1985) pp.239-267.

[7] FA Williams. "Mechanisms of fire spread. Sixteenth symposium (international) on combustion", Elsevier, vol.16, no.1, (1977) December, pp.1281-1294.

[8] IS Wichman, AM Osman, "Flame spread over a flat, combustible,thermally thick solid in an opposed oxidizer shear flow", Combust Flame, vol.112, (1998), pp.623-34.

[9] VB Apte, RW Bilger, AR Green, JG Quintiere, "Wind aided turbulent flame spread and burning over large scale horizontal PMMA surfaces", Combust Flame, vol.85, (1991), pp.169-84.

[10] B. Karlsson. "A mathematical model for calculating heat release rate in the room corner test", Fire Safety J, vol.20, (1993), pp.93-113.

[11] JG Quintiere, "The application of flame spread theory to predict materials performance", Journal of Research of the National Bureau of Standards, vol.93, no.1, (1988), pp.61-70.

[12] G. Grant, D. Drysdale. "Numerical modelling of early flame spread in warehouse fires", Fire Safety J, vol.24, no.3, (1995), pp.247-78.

[13] L. Yuan, J. Richard, J. H Mainiero, R. Richard A. Thomas, A. C. Smith "Numerical and experimental study on flame spread over conveyor belts in a large-scale tunnel", Journal of Loss Prevention in the Process Industries (2014), vol.30, pp.55-62.

[14] E.K. Stefopoulos, D.G Damigos, "Design of emergency ventilation system for an underground storage facility", Tunnelling and Underground Space Technology, vol.22, no.3, (2007), pp.293-302.

[15] L. Yuan, and A. C.. Smith, "Computational fluid dynamics modeling of spontaneous heating in longwall gob areas", SME Annual Meeting, (2007) Feb 25-28; Denver, Colorado, Preprint 07-101.

\section{Author}

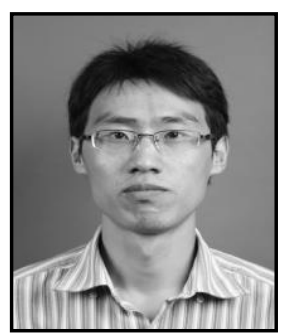

Hao Shao, he received a doctor degree in Safety Technology and Engineering (2011) from the School of Safety Engineering, China University of Mining \& Technology, Xuzhou, China. Now he is a lecturer of Safety Engineering at this school. His current research interests include prevention of mine fire and gas, computer simulation of mine hazard. 
International Journal of Security and Its Applications

Vol.9, No.12 (2015) 